\title{
WHATSAPP BUSINESS SEBAGAI ALAT BANTU PEDAGANG PASAR TRADISIONAL PADA ERA NEW NORMAL DI KOTA YOGYAKARTA
}

\author{
Wiji Nurastuti \\ Dep. of Computer Science, Amikom University, Yogyakarta, Indonesia \\ E-mail:wiwitab@amikom.ac.id
}

\begin{abstract}
Abstraksi
Indonesia di hadapkan masalah salah satunya yang paling krusial dalam segi ekonomi akibat pandemi Covid-19 khususnya para pedagang pasar tradisional Kota Yogyakarta. Memasuki tahapan new normal yaitu sebuah skenario yang digunakan untuk menangani kasus percepatan Covid-19 dalam segi kesehatan serta ekonomi, diterapkan program pasar JuWAra yang merupakan Program Pelatihan Pedagang Pasar Tradisional tapi Modern (TTM) bertujuan membekali pedagang pasar tradisional dengan keterampilan dasar digital berupa optimalisasi fungsi aplikasi WhatsApp Business untuk mempermudah interaksi antar pelanggan dengan disediakannya fitur-fitur yang memudahkan berkomunikasi dengan pelanggan, membalas pesan secara otomatis, menyortir pesan, menjawab pertanyaan pelanggan secara otomatis dan dapat juga digunakan dalam masalah pembayaran dengan mengirimkan bukti transfer. Dilakukan kegiatan kelas program pendampingan digital pasar tradisonal bersama Whatsapp secara online dan kunjungan secara offline bekerjasama dengan UKM Indonesia tercatat terdapat 9 pasar tradisional dan terpilih 3 pasar tradisonal yang diberikan E-monev. Dari kegiatan yang telah dilakukan diketahui bahwa sudah cukup banyak pedagang pasar merubah pola usaha meraka dapat dilihat dari antusias para pedagang pasar mengikuti kelas Whatsapp Business dan sudah mendaftaran akun mereka masing-masing sehingga nantinya sebagai sangat membantu dalam berkomunikasi agar usaha tetap produktif.
\end{abstract}

Kata Kunci: New Normal, Whatsapp Business, Pasar Tradisonal.

\begin{abstract}
Indonesia is faced with problems, one of which is the most crucial in terms of the economy due to the Covid-19 pandemic, especially the traders of the Yogyakarta City traditional market. Entering the new normal stage, where a scenario is used to handle cases of acceleration of Covid-19 in terms of health and economy, the JuWAra market program is implemented, which is a Traditional but Modern Market Trader Training Program aimed at equipping traditional market traders with basic digital skills in the form of optimizing the functions of the WhatsApp Business application. to facilitate interaction between customers by providing features that make it easier to communicate with customers, reply to messages automatically, sort messages, and can also be used in payment problems by sending proof of transfer. Class activities for traditional market digital mentoring programs with Whatsapp online and offline visits in collaboration with UKM Indonesian were recorded, there were 9 traditional markets and 3 traditional markets were selected that were given E-monev. From these activities, quite a lot of market traders have changed their business patterns from enthusiastically taking classes and registering accounts so that later it will be very helpful in communicating so that businesses remain productive.
\end{abstract} Keywords: New Normal, Whatsapp Business, Traditional Market

\section{PENDAHULUAN}

Pandemi Covid-19 atau Coronavirus disease 2019 yaitu suatu peristiwa menyebarnya penyakit ke seluruh dunia untuk semua negara. Salah satu penyebab penyakit ini yaitu virus jenis baru yang diberi nama SARS-CoV2 [1]. Wabah dari Covid-19 pertama kali ditemukan pada Kota Wuhan, Hubei, Tiongkok tertanggal 1 Desember 2019 dan ditetapkan oleh Organisasi Kesehatan Dunia (WHO) sebagai pandemi pada tanggal 11 Maret 2020 [2]. Penyebab persebaran virus SARS-CoV-2 dapat menyebar melalui percikan di antara orang-orang yang dihasilkan selama batuk dihasilkan dari pernapasan normal dan bersin. Selanjutnya pada virus dapat menyebar akibat menyentuh permukaan benda yang terkontaminasi dan kemudian ketika menyentuh wajah, paling menular saat penderita memiliki gejala walaupun penyebarannya mungkin saja terjadi sebelum gejala muncul. Periode waktu terkena paparan virus dan munculnya gejala biasanya sekitar lima hari hingga empat belas hari. Pada gejala umumnya yaitu demam, batuk, dan sesak napas. Pengobatan primer yang diberikan berupa terapi simtomatik dan 
suportif. Kemudian langkah-langkah pencegahan yang direkomendasikan di antaranya mencuci tangan, menutup mulut saat batuk, menjaga jarak dari orang lain, serta pemantauan dan isolasi diri untuk orang yang mencurigai bahwa mereka terinfeksi [3].

Indonesia telah di hadapkan akan masalah salah satunya yang paling krusial dalam segi ekonomi akibat dari pandemi Covid-19. Keadaan seperti ini membuat ekonomi di Indonesia nampak memprihatinkan sehingga diperkirakan akan jatuh seperti depresi di tahun 1930. Keadaan seperti ini juga akan memicu penurunan perdagangan lokal bahkan perdagangan internasional. [4]. Salah satu daerah yang terkena dampak dari pandemi yaitu Kota Yogyakarta yaitu berbagai sektor terjadi kendala dalam proses operasi, seperti halnya pabrik-pabrik yang harus menghentikan proses operasi karena kondisi tidak memungkinkan dan juga pasar-pasar lokal dan internasional lainnya. Kota Yogyakarta mencatat terkait pertumbuhan ekonomi mengalami penurunan hngga 2,22\% akibat pandemi yang berkepanjangan [5]. Kota Yogyakarta merupakan salah satu daerah di Indonesia yang selalu berkembang dalam hal kehidupan masyarakatnya, segi tata ruangnya, serta perekonomian. Dalam hal perekonomian, Kota Yogyakarta menyandarkan ekonomi melalui sektor-sektor sekunder serta tersier dalam bidang, transportasi, perdagangan, hotel, industri pengolahan, restoran, telekomunikasi, keuangan, sewa, jasa perusahaan dan jasa-jasa. Namun semenjak terjadinya pandemi Covid-19 membuat banyak perubahan dalam segi ekonomi mengalami kontraksi cukup dalam hingga angka 6,74\% dari pencapaian di bawah pertumbuhan ekonomi nasional. Hal tersebut dapat dikontrol dengan mempersiap tatanan kehidupan baru atau new normal berdampingan dengan Covid-19 [6]

Hal-hal yang dapat mengatasi permasalahn tersebut yaitu dengan adanya teknologi, sudah banyak sekali masyarakat yang memiliki akses internet dan mempunyai pengetahuan akan bagaimana cara memanfaatkan teknologi yang ada. Oleh sebab itu, new normal menjadi waktu yang tepat untuk berbenah diri dalam aspek Information and Communication Technologies (ICT). New normal atau disebut dengan kenormalan baru merupakan suatu keadaan normal yang sebelumnya tidak ada atau keadaan beradaptasi terhadap lingkungan dalam bentuk gaya hidup serta bekerja dengan tetap mengikuti protokol kesehatan bertujuan untuk tetap sehat, tetap produktif, tetap melakukan aktivitas ekonomi, dan terhindar dari virus Covid-19. Jika membahas kenormalan baru, maka banyak didapatkan hal-hal yang sebelumnya dirasa tidak normal tetapi di era new normal ini menjadi dianggap normal. New normal juga merupakan sebuah skenario yang digunakan untuk menangani kasus percepatan Covid-19 dalam segi kesehatan serta sosial-ekonomi. Pada pemerintahan Indonesia mengimplementasikan skenario new normal dengan mempertimbangkan studi epidemiologis dan kesiapan regional sejak bulan Mei 2020, karena WHO meminta menarapkan beberapa indikator agar bisa dipatuhi oleh semua negara di dunia dalam rangka menyesuaikan kehidupan new normal dengan Covid-19 [7]. Aktivitas seharihari dalam kondisi new normal lebih waspada dalam melakukan kontak fisik. Persiapan preventif seperti menggunakan masker ketika akan bepergian serta menjaga jarak dengan orang lain telah menjadi norma masyarakat baru. Selain itu, bukan saja hanya untuk mengurangi risiko transmisi virus corona saja, namun untuk untuk menjadi sebuah bentuk kesadaran dalam menjaga kesehatan [8].

Pembaruan akan teknologi meliputi hal-hal yang dapat diproduksi, proses produksi, infrastruktur lokasi, serta hukum dan ketentuan yang berlaku. Permasalahan dalam aspek ekonomi di kondisi new normal akan mengubah dunia secara total dengan penerapan teknologi [8]. Penerapan teknologi yang kerap dijumpai salah satunya yaitu penggunaan media sosial yang dapat dengan mudah menciptakan sebuah forum, individu satu dengan yang lain sehingga bisa saling berkomunikasi serta bertukar pikiran. Individu dapat membangun sebuah asumsi, emosi dan kepercayaan melalui komentar dengan sudut pandang pemikiran individu lain, hal ini memungkinkan dapat secara reaktif berkomentar dalam memberi kesimpulan [9]. Penerapan penggunaan kemajuan teknologi penting dilakukan khususnya dalam Mikro Kecil Menengah (UMKM) harus menerapkan strategi baru agar tetap produktif pada pandemi Covid-19. Jika harus ke pasar atau toko memperhatikan pertemuan dengan jarak.

Pada bulan April tahun 2021, Facebook telah mengeluarkan pengumuman akan kegiatan kampanye berkaitan dengan bulan kebaikan untuk menyambut Bulan Ramadan 2021. Kegiatan itu dipersiapkan dalam tiga hal yaitu jelajahi kebaikan, inspirasi kebaikan, serta ekspresikan kebaikan. Bentuk dari inisiatif kegiatan inspirasi kebaikan yang diadakan oleh Facebook bertajuk Pasar JuWAra yang bertujuan untuk membantu para pelaku UMKM di pasar meningkatkan penjualannya memanfaatkan layanan WhatsApp. Jenis kegiatan ini dihadirkan karena terjadinya keterbatasan yang dialami oleh masyarakat selama masa pandemi, baik pegadang hingga konsumen. Oleh sebab itu, kegiatan ini dihadirkan WhatsApp agar nantinya dapat menjembatani keterbatasan tersebut. WhatsApp Business sebagai komunikasi diantara konsumen pelanggan dengan disediakannya fitur-fitur yang dapat memudahkan dalam berkomunikasi dengan pelanggan dengan dapat membalas pesan secara otomatis, menyortir pesan, dan menjawab pertanyaan pelanggan secara cepat.

\section{METODE PENELITIAN}

Pada penelitian ini menggunakan data primer yang diperoleh dari kegiatan kelas program pada bulan April tahun 2021 bagi para pedagang pasar di seluruh Indonesia yang dimotori oleh ukmindonesia.id - LPEM FEB UI 
dan WhatsApp bernama Program Pasar JuWAra dengan memilih beberapa pasar. Program pasar JuWAra merupakan Program Pelatihan Pedagang Pasar Tradisional Tapi Modern (TTM) bertujuan membekali pedagang pasar tradisional dengan keterampilan dasar digital berupa optimalisasi fungsi aplikasi WhatsApp Business. Kota Yogyakarta dijadikan sampel dalam penelitian ini bekerja sama dengan pasar Pujokusuman, XT-Square, Ngasem, Kranggan, Prawirotaman, Serangan, dan Sentul menyelenggarakan program Pasar JuWAra (Program Pendampingan Digitalisasi Pasar Tradisional bersama WhatsApp). Jadwal kehiatan di Pasar Kota Jogja yaitu Pasar Pujokusuman 31 Maret 2021, Pasar XT Square 1 April 2021, Pasar Ngasem 5 April 2021, Pasar Kranggan 9 April 2021, Pasar Prawirotaman 10 April 2021, Pasar Sentul 11 April 2021, Pasar Serangan 14 April 2021, dan NaZMa Office (campuran beberapa pasar) 16 April 2021.

Melalui program tersebut diberikan pemahaman terkait kemampuan penguasaan terkait teknik promosi dengan media Whatsapp Business, selanjutnya pembelajaran dimulai dengan tahap instalasi aplikasi, pengenalan aplikasi, penggunaan berbagai fitur whatsapp, mengintegrasikan whatsapp dengan web dengan berbasis wordpress atau yang dikoding sendiri, cara pengumpulan database, pembuatan konten, serta tool yang digunakan untuk kemudahan dalam penggunaan. Data yang telah terkumpul berasal dari 9 pasar tradisinal yang ada di Kota Yogyakarta diberikan program pendampingan. Pada pelaksanaan kegiatan program yang dilakukan menggunakan metode pendampingan, Focus Group Discussion (FGD), online maupun offline. Setiap mitra pelatihan (pelaku usaha UMK) pada masing-masing pasar akan diedukasi dan dilakukan pendampingan dengan cara daring maupun dikunjungi oleh tim untuk diberikan pendampingan dan pelatihan. Pelaksanaan kegiatan ini juga terdiri atas analisis awal, persiapan, pelaksanaan, serta evaluasi [11].

\section{HASIL DAN PEMBAHASAN (12pt, Bold, Capital)}

Indonesia telah di hadapkan akan masalah salah satunya yang paling krusial dalam segi ekonomi akibat dari pandemi Covid-19 khususnya para pedagang pasar tradisional. Kondisi tersebut sangat penting untuk penerapan teknologi seperti Whatsapp Business sebagai alat bantu di era new normal bagi pedagang pasar. Analisisi deskriptif berfungsi dalam menampilkan gambaran dari sebuah data agar mudah dipahami dan lebih informatif. Analisis deskriftif mampu memberikan gambaran dari pengguna Whatsapp bisnis sebagai alat bantu di era new normal bagi pedagang pasar. Berikut pada Tabel 1 dan 2 merupakan tampilan dari tabel daerah yang telah mengikuti pendampingan Whatsapp Business yang telah diadakan oleh UKM Indonesia serta kategori produk yang dijual:

Tabel 1. Kabupaten/Kota Pengguna Whatsapp Business

\begin{tabular}{|c|c|c|}
\hline Provinsi & Kabi & Jumlah \\
\hline \multirow[t]{2}{*}{ Aceh } & Aceh Besar & 42 \\
\hline & Banda Aceh & 2 \\
\hline \multirow[t]{3}{*}{ Sumatra Utara } & Toba & 9 \\
\hline & Gunungsitoli & 21 \\
\hline & Padang & 5 \\
\hline Sumatra Selatan & Lubuk Linggau & 21 \\
\hline Bengkulu & Bengkulu & 5 \\
\hline \multirow[t]{2}{*}{ Riau } & Dumai & 31 \\
\hline & Pekanbaru & 2 \\
\hline Banten & Serang & 77 \\
\hline \multirow[t]{3}{*}{ DKI Jakarta } & Jakarta Pusat & 21 \\
\hline & Jakarta Selatan & 13 \\
\hline & Jakarta Utara & 25 \\
\hline \multirow[t]{2}{*}{ DIY } & Bantul & 14 \\
\hline & Yogyakarta & 59 \\
\hline Jawa Barat & Cianjur & 18 \\
\hline \multirow{5}{*}{ Jawa Tengah } & Banjarnegara & 4 \\
\hline & Batang & 2 \\
\hline & Wonosobo & 16 \\
\hline & Salatiga & 1 \\
\hline & Pekalongan & 17 \\
\hline \multirow[t]{2}{*}{ Jawa Timur } & Mojokerto & 3 \\
\hline & Sidoarjo & 3 \\
\hline Bali & Jembrana & 4 \\
\hline
\end{tabular}




\begin{tabular}{|l|l|l|} 
& Provinsi & \multicolumn{2}{c}{ Jumlah } \\
\hline NTT & Kupang & 14
\end{tabular}

Selanjutnya akan dilakukan visualisasi data berupa tampilan peta dan grafik untuk mengetahui gambaran dari data terkait informasi pengguna Whatsapp bisnis pada pedagang pasar di era new normal agar data yang tersaji menjadi lebih mudah dipahami dan informatif bagi pembaca. Berikut pada Gambar 1 merupakan tampilan peta daerah dengan banyaknya pengguna Watsapp bisnis.

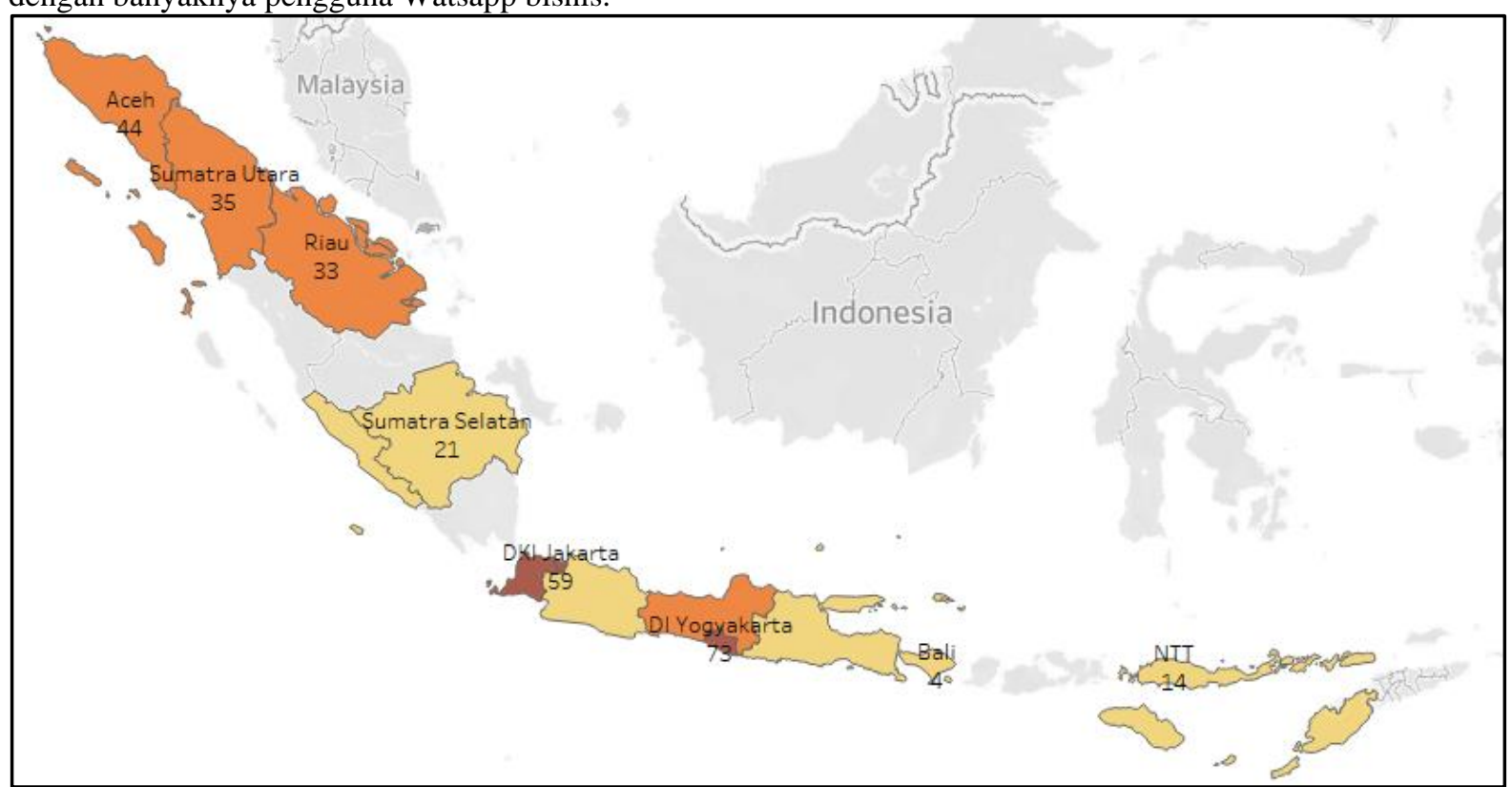

Gambar 1. Provinsi Pengguna Whatsapp Bisnis

Didapatkan hasil bahwa terdapat 38,23\% provinsi dari 34 provinsi di Indonesia yaitu 13 provinsi yang tercatat dari data hasil yang diperoleh dari kegiatan kelas Whatsapp Business. Terdapat 3 gradasi warna yaitu warna kuning, orange, dan coklat. Kuning menunjukkan daerah yang jumlah pengguna rendah diantaranya Provinsi Bali sebanyak 4, Provinsi Bengkulu sebanyak 5, Provinsi Jawa Timur sebanyak 6, Provinsi NTT sebanyak 14, Provinsi Jawa Barat sebanyak 18, dan Provinsi Sumatra Selatan sebanyak 21. Selanjutnya warna orange dengan daerah yang jumlah pengguna sedang yaitu Provinsi Riau sebanyak 33, Provinsi Sumatra Utara seabanyak 35, Provinsi Jawa Tengah sebanyak 40, dan Provinsi Aceh sebanyak 44. Kemudian warna coklat dengan daerah yang jumlah pengguna tinggi yaitu Provinsi DKI Jakarta sebanyak 59, Provinsi DI Yogyakarta sebanyak 73, dan Provinsi Banten sebanyak 77. Dapat diketahui, Provinsi dengan pengguna yang banyak yaitu Provinsi Banten dan Provinsi dengan jumlah pengguna terendah yaitu Provinsi Bali.

Tabel 2. Kategori Produk yang Dijual

\begin{tabular}{|l|c|}
\hline \multicolumn{1}{|c|}{ Kategori } & Jumlah \\
\hline Aneka kemasan plastik sterofom & 5 \\
\hline ATK dan jasa percetakan, jahit, fotokopi, pulsa & 18 \\
\hline Bahan pangan segar, sayur, daging, ayam, ikan & 125 \\
\hline Buah-buahan & 32 \\
\hline Bumbu, sambal, rempah, jamu, madu & 35 \\
\hline Cemilan, krupuk, kripik, kue & 142 \\
\hline Dekorasi rumah & 11 \\
\hline Depot air isi ulang & 2 \\
\hline Furnitur, mabel, teralis & 18 \\
\hline Ikan asin, teri, abon, olahan ikan lain & 28 \\
\hline Jasa salon, spa, potong rambut, tata rias & 3 \\
\hline Kerajinan gerabah, bamboo, rotan, rajut & 21 \\
\hline Kosmetik dan perawatan tubuh & 23 \\
\hline Makan dan minuman siap saji & 201 \\
\hline Peralatan dan perlengkapan elektronik & 5 \\
\hline Perhiasan emas, perak, mutiara, batu permata & 8 \\
\hline
\end{tabular}




\begin{tabular}{|l|c|}
\hline \multicolumn{1}{|c|}{ Kategori } & Jumlah \\
\hline Perlengkapan pertanian & 2 \\
\hline Ragam pakaian, gamis, aksesoris, dan mainan & 287 \\
\hline Ragam produk hobi, sepeda, olahraga, ikan hias, tanaman & 15 \\
\hline Sembako dan kelontong & 105 \\
\hline
\end{tabular}

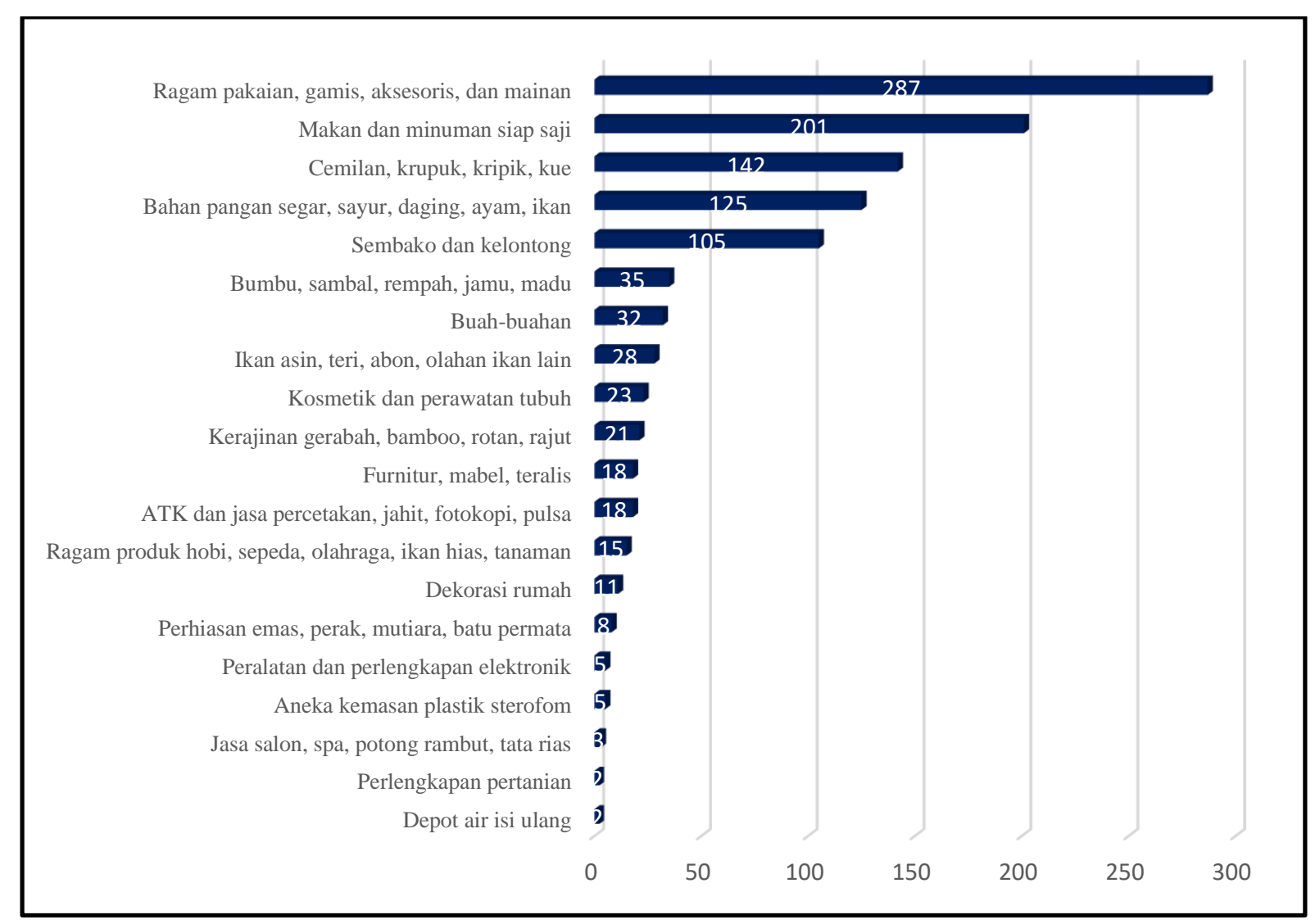

Gambar 2. Grafik Batang Kategori Produk yang Dijual

Kategori produk yang dijual dikelompokan sebanyak 20 kategori produk yang dijual. Terdapat kategori ragam pakaian, gamis, aksesoris, dan mainan yang merupakan kategori tertinggi sebanyak 287 pedagang, selanjutnya terdapat makanan dan minuman siap saji juga menduduki kategori tertinggi sebanyak 201 pedagang, dan cemilan, krupuk, kripik, dan kue juga menduduki kategori tinggi sebanyak 142 pedagang. Sedangkan dengan kategori terendah yaitu ada pada kategori depot air isi ulang sebanyak 2 pedagang, selanjutnya pada kategori perlengkapan perteanian juga sebanyak 2 pedagang, kemuudian pada kategori jasa salon, spa, potong rambut, dan tata rias sebanyak 3 pedagang. Program tersebut yang dilakukan oleh peneliti yaitu hanya pada Kota Yogyakarta, terdapat beberapa faktor yang yang mendukung jalannya program yang telah dilaksanakan yaitu tim pelaksana yang kompeten, partisipasi peserta dan masyarakat. Faktor pendukung selanjutnya yaitu adanya dukungan yang kuat dari beberapa pihak khusunya pemerintah Kota Yogyakarta.

Kemudian faktor pendukung yaitu partisipasi dan keterlibatan para peserta dalam hal ini pelaku UMK dan UMKM dari pasar tradisional sehingga dapat terjadi saling belajar di antara para peserta program. Adapun faktor pendukung yang terakhir yaitu fasilitas, sarana prasarana pendukung dari institusi maupun dari masyarakat. Selanjutnya diberikan gambaran data yang mampu memberikan hasil dari kegiatan pendampingan digital pasar tradisonal dalam penggunan Whatsapp Business sebagai alat bantu di era new normal bagi pedagang pasar tradisional di Kota Yogyakarta yang telah dilaksanakan pada bulan April tahun 2021. Berikut pada Tabel 3 merupakan data dari daftar pasar-pasar dan lokasinya yang telah diberikan pendampingan: 
Tabel 3. Daftar Pasar

\begin{tabular}{|l|l|}
\hline \multicolumn{1}{|c|}{ Nama Pasar } & \multicolumn{1}{c|}{ Alamat } \\
\hline XT Square & Jl. Veteran No. 150-151, Pandeyan, Kec. Umbulharjo, Kota Yogyakarta \\
\hline Pasar Pujokusuman & J1. Sisingamangaraja, Keparakan, Kec. Mergangsan, Kota Yogyakarta \\
\hline Pasar Kranggan & Jl. Pangeran Diponegoro, Gowongan, Kec. Jetis, Kota Yogyakarta \\
\hline Pasar Serangan & Jl. R. E. Martadinata, No. 2, Pakuncen, Wirobrajan, Kota Yogyakarta. \\
\hline Pasar Prawirotaman & J1. Parangtritis No. 103, Brontokusuman, Kec, Margangsan, Kota Yogyakarta. \\
\hline Pasar Kutu & Jl. Wijaya Kusuma, Kutu Dukuh, Sindudadi, Kec. Mlati, Kab. Sleman. \\
\hline Pasar Lempuyangan & J1. Hayam Wuruk No. 179, Tegal Panggung, Kec. Danurejan, Kota Yogyakarta \\
\hline Pasar Sentul & Jl. Sultan Agung No. 52, Gunungketur, Pakualaman, Kota Yogyakarta \\
\hline Pasar Ngasem & Jl. Polowijan No. 11, Patehan, Kec. Kraton, Kota Yogyakarta. \\
\hline
\end{tabular}

Sebanyak 8 pasar tradisonal di Kota Yogyakarta dan 1 pasar tradisional di Kabpupaten Sleman yang telah diberikan pendampingan terkait digital pasar tradisional dalam penggunaaan Whatsapp Business terpilih 3 pasar yang masuk ke tahap E-monev selanjunya. E-monev merupakan sebuah sistem informasi monitoring dan evaluasi pelaksanaan diantaranya XT Square, Pasar Prawirotaman, dan Pasar Kranggan agar nantinya para pedagang memiliki keinginan untuk menyeimbangkan antara pasar tradisional dan modern, para pedagang harus bisa menyusun kelompok kerja yang dibentuk dari komunitas pasar, agar dapat mengelola pasar dengan baik menggunakan digital di era new normal. Berikut pada Gambar 3 merupakan dokumentasi-dokumentasi dari kegiatan yang berlangsung di lapagan.

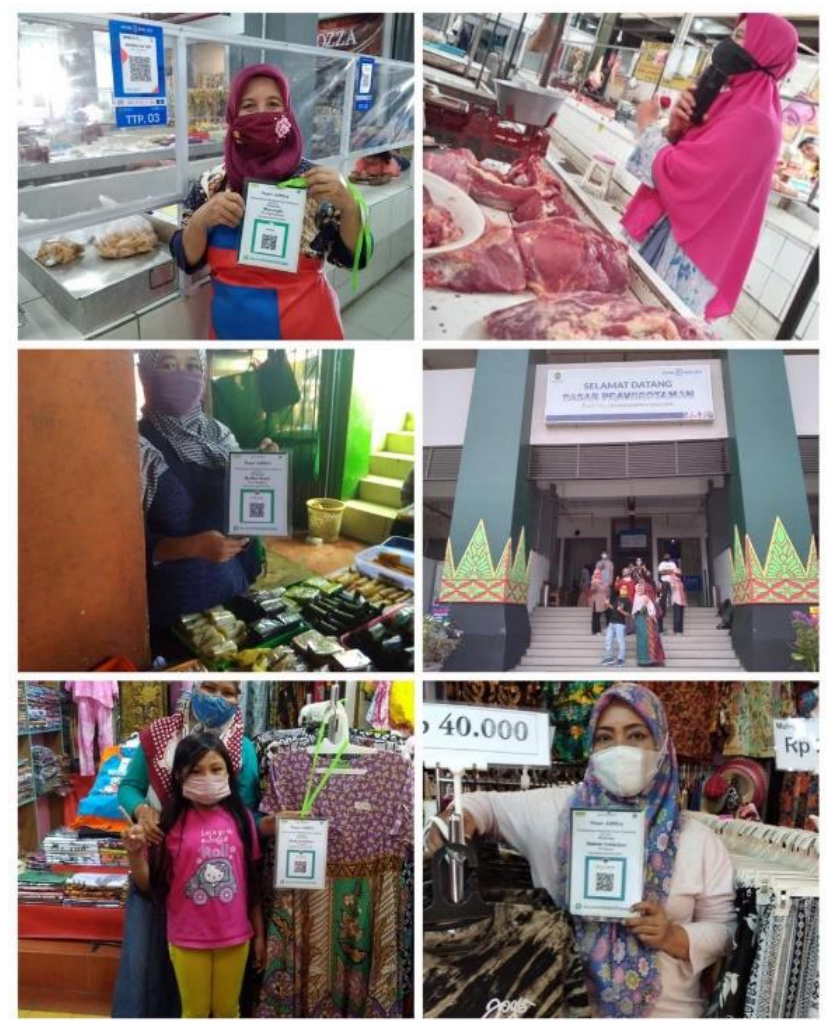

Gambar 3. Dokumentasi Kegiatan di Lapangan

Dari kegiatan yang telah dilakukan dapat diketahui bahwa sudah cukup banyak pedagang pasar merubah pola usaha meraka dapat dilihat dari antusias para pedagang pasar mengikuti kelas Whatsapp Business dan sudah mendaftaran akun mereka masing-masing. Perubahan aktivitas yang terjadi pada masyarakat di era new normal karena Covid-19 mengakibatkan beberapa bidang khusunya bisnis di lingkungan pasar perlu merubah pola usahanya menjadi online. Salah satu yang bisa digunakan yaitu Whatshap Business sebagai alat bantu komunikasi media sosial yang telah cukup popular agar usaha tetap produktif. 


\section{KESIMPULAN}

Dari analisis yang dilakukan oleh peneliti, didapatkan beberapa kesimpulan yaitu perubahan atas kegiatan yang disebabkan oleh pandemi Covid-19 membuat masyarakat harus menyesuakan diri di era new normal khususnya para bisnis pedagang pasar tradisonal agar tetap bisa berjalan dengan baik. Penggunaan Whatsapp Business menjadi salah satu alat bantu komunikasi antara pedagang dan konsumen agar tidak menurunnya daya beli masyarakat. Selanjutnya didaptkan hasil analisis yaitu pedagang pasar pada provinsi yang ada di Pulau Jawa dan Pulau Sumatra sudah cukup banyak menggunakan Whastaap Business kemudian kategori produk yang banyak dijual melalu Whatsapp Business yaitu pakaian dan makanan. Selanjutnya didapatkan hasil dari kegiatan yaitu pedagang pasar tradisional di Kota Yogyakarta yang lolos dari 9 pasar yaitu 3 pasar dalam E-monev, dimana dilakukan sebuah sistem informasi monitoring dan evaluasi pelaksanaan diantaranya XT Square, Pasar Prawirotaman, dan Pasar Kranggan.

\section{DAFTAR PUSTAKA}

[1] A. E. Gorbalenya, "Severe acute respiratory syndrome-related coronavirus - The species and its viruses, a statement of the Coronavirus Study Group," 11 Februari 2020. [Online]. Available: https://doi.org/10.1101/2020.02.07.937862. [Accessed 10 Juni 2021].

[2] WHO, "WHO Director-General's opening remarks at the media briefing on COVID-19 - 11 March 2020," 11 Maret 2020. [Online]. Available: www.who.int. [Accessed 10 Juni 2021].

[3] H. A. Rothan and S. N. Byrareddy, "The epidemiology and pathogenesis of coronavirus disease (COVID19)," 2 Februari $2020 . \quad$ [Online]. https://www.sciencedirect.com/science/article/abs/pii/S0896841120300469?via\%3Dihub. [Accessed 10 Juni 2021].

[4] Nurhidayati and A. K. Anam, Manajemen Bisnis di Era Pandemi Covid-19 dan New Normal, Semarang: Unissula Press, 2020.

[5] M. Dr. Subandi Sardjoko, Studi Pembelajaran Penanganan COVID-19 di Indonesia, Jakarta: Direktorat Kesehatan dan Gizi Masyarakat Bappenas, 2021.

[6] B. RI, "Dampak Dari Pandemi COVID-19, Perekonomian di DIY Alami Kontraksi 6,74 \%," 18 Januari 2021. [Online]. Available: https://yogyakarta.bpk.go.id/dampak-dari-pandemi-covid-19/. [Accessed 12 Juni 2021].

[7] W. Mas'udi and P. S. Winanti, Perubahan Sosial Ekonomi dan Politik Pademi Covid-19, Yogyakarta: Gajah Mada University Press, 2020.

[8] P. Agung Trisetyarso, "MENGAWALI NEW NORMAL, 3 ASPEK PENTING YANG AKAN BERUBAH DI NEW SOCIETY," 21 Juli 2020. [Online]. Available: https://dcs.binus.ac.id/2020/07/21/mengawalinew-normal-3-aspek-penting-yang-akan-berubah-di-new-society/. [Accessed 11 Juni 2021].

[9] Trisani, " Pemanfaatan Whatsapp Sebagai Media Komunikasi dan Kepuasan Dalam Penyampaian Pesan Dikalangan Tokoh Masyarakat," Jurnal Komunikasi, Media, dan Informatika, p. 6, 2017.

[10] W. Nurastuti, Metode Riset, Purworejo: Rajawali Press, 2009.

[11] A. M. Damar, "Faceebok Gelar Pelatihan Whatsapp Bisnis untuk Pedagang Pasar Jelang Ramadhan 2021," 9 April 2021. [Online]. Available: https://www.liputan6.com/tekno/read/4527136/facebook-gelarpelatihan-whatsapp-business-untuk-pedagang-pasar-jelang-ramadan-2021. [Accessed 11 Juni 2021].

\section{Biodata Penulis}

Wiji Nurastuti, alumni FE UMS Solo 2001 dan MTI UGM di 2005. Saat ini aktif di Asean Mentorship (AMEN), Markplus Institute, Asean Coaching Alliance, UKM Indonesia( UI) dan Lunas. Aktif mengajar du Prodi Sistem Informasi Univ Amikom Yogyakarta. Certified Export, Marketing ( Service Brand, Product), Licenced Coach Profesional. 